\title{
Metal concentrations in selected organs and tissues of five Red-knobbed Coot (Fulica cristata) populations
}

\author{
Pieter $\mathrm{H}$ van Eeden \\ EcoMonitor cc, PO Box 13434, Norkem Park 1631, South Africa
}

\begin{abstract}
The Red-knobbed Coot Fulica cristata is an abundant aquatic bird in South Africa and was anticipated to have indicator abilities for metal pollution. This hypothesis was tested on 83 coot samples collected from five selected aquatic ecosystem areas supporting substantial coot populations, of which various abiotic and biotic components are known to contain varying levels of a number of metals. The aim of this study was achieved by determining the variations in $\mathrm{Cd}, \mathrm{Cu}, \mathrm{Ni}$ and $\mathrm{Pb}$ concentrations in liver, kidney, bone and blood samples, with the use of standard flame atomic absorption spectrophotometry techniques. Coots from the Germiston Lake sampling site showed the highest concentrations of cadmium in liver $(2.2 \mu \mathrm{g} / \mathrm{g} \mathrm{d.w.})$ and kidney $(5.4 \mu \mathrm{g} / \mathrm{g} \mathrm{d}$.w.). The absence of metalprocessing industries in the catchments of the Florida Lake and the Steynsrus farm dams reflects the low liver and kidney concentrations of $\mathrm{Cd}, \mathrm{Ni}$ and $\mathrm{Cu}$, respectively. The blood of the Natalspruit wetland coots contained the highest dry weight concentrations of $\mathrm{Ni}(11.4 \mu \mathrm{g} / \mathrm{g}), \mathrm{Cd}(1.8 \mu \mathrm{g} / \mathrm{g})$ and $\mathrm{Cu}(14.4 \mu \mathrm{g} / \mathrm{g})$. The statistical evaluation points towards small-scale geographical differences, especially in the concentrations of $\mathrm{Cu}, \mathrm{Ni}$ and $\mathrm{Pb}$ and in the liver, kidney and blood. However, in terms of actual metal concentrations recorded, no significant differences existed between coots of the reference site (Steynsrus farm dams) and those from the other four localities. It is concluded that the impact of metal-containing diets on the tissue concentrations of these metals in birds plays a far more significant role compared to the migratory habits or short-range movements of the coots.
\end{abstract}

Keywords: metals, liver, blood, bone, kidney, Red-knobbed Coot, Fulica cristata

\section{Introduction}

It is documented that a variety of metals are of strategic importance to the industrial world (Greenwood and Earnshaw, 1984). Unfortunately, some metal-processing industries are responsible for various forms of environmental pollution. This results in various impacts on living organisms, including birds, when metal-containing liquid or solid wastes are knowingly or unknowingly discharged into freshwater ecosystems (White and Kaiser, 1976; Kempf and Sittler, 1977; Bull et al., 1983; Ohlendorf et al., 1986). These industrial spillages stimulated the research into the possible use of aquatic organisms to evaluate and monitor the various forms of pollution (e.g. Nybø et al., 1996; Miles and Tome, 1997; Hernández et al., 1999). Certain aquatic or semi-aquatic birds are among the few vertebrate species that have been used as biological monitors of environmental pollution, especially metal pollution. For instance, Munoz et al., 1976) found that the Laughing Gull (Larus atricilla) was a useful biological monitor of $\mathrm{Pb}$ pollution. In order to be successful indicator organisms, these and other birds need to comply with certain requirements (Phillips, 1977; Ellenberg et al., 1985). They should accumulate metals without being killed by the levels encountered and they should also exhibit a high concentration ratio for metals, allowing direct analysis without the need for any pre-concentration steps. These birds should also have a relatively sedentary home-range behaviour, be abundant in the study region, be sufficiently long-lived to allow sampling of more than one year-class and be of reasonable size in order to allow for the provision of adequate tissues and/or organs for analysis. Their food composition should also be known.

IIII+2711 972-5298; fax: +2711 972-5298;

e-mail: pieter.vaneeden@absamail.co.za

Received 24 October 2001; accepted in revised form 19 April 2003.
In view of the available information, the Red-knobbed Coot (Fulica cristata) can easily qualify as a potential indicator. The Red-knobbed Coot was considered to be the most reliable choice for this study because it was anticipated to have indicator abilities as outlined above and was also abundant.

The water resources of South Africa are under serious threat from metal-containing effluents from industries, mines, sewage purification works, suburban areas and agricultural practices (Department of Water Affairs, 1986) which can seriously influence the aquatic environment and in particular the associated aquatic avifauna. This threat led to this investigation which was subsequently conducted at five selected aquatic ecosystems, which were known to be subjected to various degrees of pollution. The areas surveyed included the Natalspruit wetlands and adjacent Vlakplaats Water Pollution Control Works (WPCW), the Germiston and Florida lakes and the Marievale Bird Sanctuary, all situated within Gauteng Province. A reference site located in the agricultural districts of the Steynsrus-Senekal region in the eastern Free State Province was used for comparative purposes.

Surveys of the available literature suggested that little information exists on the ranges of natural and/or pollution levels of metals accumulated in the organs and tissues of the genus Fulica from metalcontaminated aquatic environments. This problem has to some extent been addressed by research into the concentrations of seven metals in 16 organs and tissues of the Red-knobbed Coot from a known metal-polluted aquatic environment in Gauteng Province (Van Eeden and Schoonbee, 1992; 1993).

The aim was to determine whether the Red-knobbed Coot could be an efficient and reliable regional indicator organism of metal contamination by measuring variations in cadmium $(\mathrm{Cd})$, copper $(\mathrm{Cu})$, nickel $(\mathrm{Ni})$ and lead $(\mathrm{Pb})$ concentrations in the liver, kidney, bone and blood of birds collected from five widely separated populations. 


\section{Description of the five study localities}

\section{The Natalspruit wetlands and the Germiston Lake}

Tributaries of the Elsburgspruit and the Natalspruit river systems drain the East Rand, which is the most highly developed industrial region on the Witwatersrand, among others. These rivers eventually discharge into the Klip River, via the Rietspruit. The ElsburgspruitNatalspruitriver system complex includes extensivenatural wetlands. This relatively small river catchment covers an area of approximately $225 \mathrm{~km}^{2}$ and drains a part of the Ekurhuleni Metropol consisting of the Germiston, Elsburg, Boksburg and Alberton service centres, as well as the eastern regions of the Johannesburg Metropol. Approximately 1800 industries, ranging from large chemical industries to small one-man engineering firms, occur in this area(Viljoen etal., 1985). The only active gold mine in this particular catchment area is the East Rand Proprietary Mines (ERPM) situated in Boksburg. For the rest, effluents and seepage waters originate from old mine and slimes dams as well as stone dumps. During summer, the water of the Elsburgspruit-Natalspruit river system consists of approximately $60 \%$ by volume of seepage and effluents from mines, industries, sewage purification works as well as from urban areas. In winter, the effluents from mines and industries usually comprise the bulk of the water flowing in most of the streams of this particular catchment area. Such effluents are the major sources of a variety of pollutants, including dissolved metals (Viljoen et al., 1985; Jones et al., 1989). The coots used in this investigation were all collected in the vicinity of the Natalspruit wetlands $\left(26^{\circ} 22^{\prime} \mathrm{S} 28^{\circ} 10^{\prime} \mathrm{E} ; 2628 \mathrm{AC}\right)$ adjacent to the Vlakplaats Water Pollution Control Works (WPCW), either from the wetlands proper or from the oxidation ponds of the sewage works.

Germiston Lake, also known as Victoria Lake (26 $14^{\prime} \mathrm{S} 28^{\circ} 09^{\prime}$ E; 2628AA) is situated in the headwaters of a tributary of the Elsburgspruit system and was used since 1904 as a reservoir for effluents from the now defunct Simmer and Jack mine (Dolan, 1961). It has a small natural catchment area that comprises about 1100 hectares. It is a relatively small lake with a surface area of approximately 58 ha when full (De Wet, 1990b). Currently the lake receives effluents from industrial areas as well as surface runoff from urban areas.

A number of metals with varying concentration ranges have been recorded from these two sampling areas (Vermaak, 1972; Viljoen, 1974; Schoonbee and Van der Merwe, 1989; Bezuidenhout et al., 1990; De Wet, 1990b; Van Eeden, 1990; Van Eeden and Schoonbee, 1991, 1992, 1993, 1996; Adendorff, 1992; Steenkamp, 1992; Fleischer, 1993; Steenkamp et al., 1993; Van Eeden, 1994, 2003).

\section{The Marievale and Daggafontein wetlands}

The Blesbokspruit river system is also situated on the East Rand and traverses the municipal areas of Benoni, Springs, Nigel and Heidelberg along its way to the Vaal River. This area maintains a high economic importance, especially due to its mining and industrial activities. For decades now this river system has been subjected to effluents originating from mines, industries, sewage works, urban areas and agricultural land, which are known to have polluted the natural aquatic environments found in this wetland area (Viljoen, 1974; De Wet, 1990a; De Wet et al., 1990). This river system includes several aquatic habitats such as the Alexander, Cowles and Nigel dams, the Spaarwater pan and the Springs, Marievale and Daggafontein bird sanctuaries.

A number of metals with varying concentration ranges have been recorded from this wetland area (Viljoen, 1974; De Wet, 1990a; De
Wet et al., 1990; Van Eeden, 1994). Coots were collected from suitable sites in the vicinity of the Daggafontein locality as well as from sites in the vicinity of the Marievale Bird Sanctuary $\left(26^{\circ} 21^{\prime}\right.$ S $28^{\circ} 30^{\prime} \mathrm{E} ; 2628 \mathrm{BC}$ ), both adjacent to each other.

\section{The Florida Lake}

The Florida Lake is located in the municipal area of Roodepoort $\left(26^{\circ}\right.$ $11^{\prime} \mathrm{S} 27^{\circ} 54^{\prime} \mathrm{E}$; 2627BB) on the West Rand. The lake is situated in the headwaters of the Klip River system, a tributary of the Vaal River. The present lake was created when the river on the farm Vogelstruisfontein was impounded during 1887 and 1888 (The Roodepoort Mail, 1898) both for irrigation purposes and also to provide the then existing Bantjies gold mine with water. Two small perennial streams feed the Florida Lake, which mainly drains urban areas. It is a relatively small lake with a surface area of approximately 26,5 hectares when full (Venter and Schoonbee, 1991).

Currently, the Florida Lake does not appear to be seriously affected by effluents originating from industries, mines or agricultural areas (Venter, 1991; Venter and Schoonbee, 1991), but even though the Bantjies mine itself is presently inactive, this mine is still contributing sediment-bound metal pollutants to the lake water. An old disused mine dump in the catchment of this lake is also contributing metal-containing effluents and seepage water to the Florida Lake (Venter, 1991). Presently, the only other major sources of metalcontaining effluents are the drainage waters and street run-off from surrounding urban areas and from the central business district of Florida, and possibly the adjacent local municipal swimming pool that is periodically emptied into the lake (Venter, 1991).

A number of metals with varying concentration ranges have been recorded from these two sampling areas (Viljoen, 1974; Venter, 1991; Adendorff, 1992; Van Eeden, 1994), the source of most of which may be traced to past mining operations at the turn of the century. This lake is considered to be mainly mesotrophic although eutrophic conditions may occasionally occur(Venter, 1991; Venter and Schoonbee, 1991). Considering the relatively high concentrations of metals found in the lake and the fact that the Red-knobbed Coot was the most numerous bird species on this particular lake (Venter, 1991), it was decided to collect coots from this lake.

\section{The Steynsrus-Senekal area}

The five farm dams sampled for this investigation is situated between the towns of Steynsrus and Senekal (27 $32^{\circ}$ ' S $27^{\circ} 55^{\prime}$ E and $27^{\circ} 37^{\prime}$ $\mathrm{S} 28^{\circ} 20^{\prime} \mathrm{E}$ ). It was chosen as a reference area because this area was found to contain small concentrations of metals in the water and sediments (Van Eeden, unpublished data) and is also not affected by metal-containing effluents from mines or industries. The municipal areas of these two towns are both situated in the central to eastern part of the Free State Province, covering mostly prime agricultural land. The major crops produced on these farms are maize, wheat and sunflowers. There are a few small perennial rivers in this area and the only sources of water are ground and surface runoff waters, impounded in earthen dams. The only possible sources of metalcontaining effluents are from urban drainage and street runoff(due to automobile wear), agricultural chemicals and fertilisers, as well as atmospheric deposition. These types of effluent and runoff are potential sources of metal as has been documented by Williams and David (1973), Stenström and Vahter (1974) and Sadiq et al. (1989). A number of metals with varying concentration ranges have been recorded from these farm dams (Van Eeden, 1994). Red-knobbed Coots were abundant at the various farm impoundments. 


\section{Materials and methods}

All the coots were collected at the various study areas with the various landowners' permission, and the regional permits were procured from the relevant authorities. Collections were made during the course of 1991 and 1992. Use was made of various methods of collection, but in most cases shooting $(\mathrm{Pb} 0.22$ rounds and shotgun shot) was used to collect virtually all bird specimens since this method proved to be the most successful. Following collection, each individual bird was wrapped in a plastic bag, labelled and placed in a cool box. All samples were taken to the Research Unit for Aquatic and Terrestrial Ecosystems, housed within the Zoology Department of the Rand Afrikaans University. Coots were either immediately dissected for the various organs and tissues to be analysed or else frozen for later dissection. After thawing, each individual bird was wiped down with a cloth to remove any loose foreign particles and blood. After each bird was lightly dried with paper towels to remove excess moisture, its wet mass was accurately determined to two decimals on an electronic balance.

Precautionary steps were taken in order to prevent possible metal contamination during the various procedures of laboratory analysis. All the dissections on bird samples were carried out using thoroughly washed stainless steel tools on a clean polyethylene work surface. All sample collection bottles, boro-silicate glassware used to store the various dried samples and the digestates, as well as the glassware used during the digestion procedure, were cleaned in the following manner. Firstly, all laboratory ware was thoroughly washed with a $2 \%$ detergent (Contrad Concentrate), then rinsed in doubledistilled water, soaked in a polyethylene bath filled with a $1 \mathrm{M}$ hydrochloric acid solution (BDH Chemicals) for a period of at least $48 \mathrm{~h}$, again rinsed in double-distilled water and then dried at room temperature. This procedure ensures that the laboratory ware used was thoroughly clean and practically metal-free, although it was not tested as such.

The entire liver and kidney, as well as the central shaft of the tibio-tarsus (taken as representative of the skeleton and further referred to as "bone") were dissected out. A blood sample, which usually consisted of clots, was carefully scooped from the body cavity of each bird with the aid of a clean stainless steel spoon. $\mathrm{Pb}$ shot remaining in the carcasses were removed as they were found. All the organs, with the exception of the blood, were rinsed in running, lukewarm tap water to remove excess blood. This procedure was necessary to minimise possible contamination of the various dissected organs with metal-containing blood. All muscle and connective tissues adhering to the bone samples were also carefully removed by scrubbing with a steel-wire brush available in hardware stores. All the organs and tissues were placed in separate, labelled, acid-washed, metal-free glass bottles, and then weighed on an electronic balance (accurate to two decimals) to determine the wet mass of each sample. In order to eliminate possible $\mathrm{Pb}$ contamination, tissue samples of concern were carefully scrutinised for obvious entry wounds caused by shotgun pellets or 0.22 rounds. The tissue surrounding the entry wounds was cut away and discarded. The remaining tissue was treated as described for metal determination.

The individual organ and tissue samples (including the blood) were oven dried at $90^{\circ} \mathrm{C}$ for $48 \mathrm{~h}$, or until a constant dry mass was achieved, after which the dry mass was determined. Dried material was used in this study because it has been demonstrated that the variations in the metal concentrations of a particular organ can be ascribed in large measure to the varying moisture contents of that organ (Adrian and Stevens, 1979). In all cases the entire organs, tissues or blood samples were used for metal analysis. A summary of the percentage moisture for each organ or tissue is given in Table 1 in order to facilitate the conversion of dry mass-based metal concentrations to wet mass-based metal concentrations. The values obtained during this study compare favourably with some published results $(72.5 \pm 1.6 \%$ for liver of $F$. americana (Hui, 1998)).

A $1: 1(\mathrm{v} / \mathrm{v})$ mixture of concentrated nitric acid (55\% Saarchem) and concentrated perchloric acid (60\% Labchem) was used. The samples were digested in 10-20 m $\mathrm{l}$ of this acid mixture at room temperature for at least $48 \mathrm{~h}$. The cold digestion procedure used eliminates the risk of a violent reaction between the easily oxidisable samples and the acids, which may occasionally lead to spontaneous combustion(VanEeden, personal observations). The partially digested samples were then completely digested at approximately $200^{\circ} \mathrm{C}$ on a Gallenkamp hot plate for approximately $24 \mathrm{~h}$ or for longer periods, until a clear solution was obtained (Standard Methods, 1989). During the digestion process, each beaker was covered with a watch glass to reduce evaporation and, in the process, to prevent the possible loss of metals. Following digestion, the solutions were filtered through $0.45 \mu \mathrm{m}$ acid-resistant filter paper (Commercial Papers) into $100 \mathrm{~m} \ell$, clean, acid-washed, metal-free volumetric flasks, after which the filter papers were thoroughly rinsed with double-distilled water to minimise the retention of metals. The filtrates were then made up to volumes of $100 \mathrm{~m} \ell$ with doubledistilled water. All samples were stored for later metal analyses, in labelled, acid-washed, metal-free glass bottles and covered with acid-washed, metal-free Bakelite screw tops.

The concentrations of metals in all the digestates were determined by air-acetylene flame atomic absorption spectrophotometry (AAS; Varian SpectrAA 10 series) according to standard operational procedures (Varian, 1989). The AAS was calibrated for each metal with a suitable range of standards (Saarchem Chemicals), which were made up according to standard analytical procedures. Doubledistilled water was used throughout as a blank and continually

\begin{tabular}{|l|c|c|c|c|c|}
\hline \multicolumn{7}{|c|}{$\begin{array}{c}\text { TABLE 1 } \\
\text { Percentage moisture ( } \mathbf{x} \pm \text { SD) in the organs and tissues of coots collected } \\
\text { from the five different localities }\end{array}$} \\
\hline Locality & $\mathbf{n}$ & Liver & Kidney & Bone & Blood \\
\hline Natalspruit wetland & 18 & $76.7 \pm 3.6$ & $82.6 \pm 2.2$ & $16.4 \pm 5.5$ & $73.8 \pm 5.2$ \\
Marievale wetland & 20 & $78.6 \pm 1.8$ & $85.2 \pm 1.7$ & $15.5 \pm 6.9$ & $75.5 \pm 3.6$ \\
Germiston Lake & 9 & $79.5 \pm 1.8$ & $84.6 \pm 1.2$ & $14.4 \pm 3.5$ & $73.8 \pm 3.8$ \\
Florida Lake & 15 & $78.3 \pm 2.2$ & $83.0 \pm 2.0$ & $15.6 \pm 3.8$ & $74.3 \pm 3.1$ \\
Steynsrus farm dams & 21 & $78.8 \pm 3.3$ & $84.8 \pm 1.2$ & $13.5 \pm 3.2$ & $71.3 \pm 3.6$ \\
Total or mean & 83 & $78.4 \pm 1.0$ & $84.0 \pm 1.2$ & $15.1 \pm 1.1$ & $73.7 \pm 1.5$ \\
\hline
\end{tabular}


TABLE 2

Concentrations ( $\mu \mathrm{g} / \mathrm{g}$ dry mass) of metals in liver from five Redknobbed Coot populations. Results are given as $\bar{x} \pm S D$, coefficient of variation (\%) and range (minimum - maximum)

\begin{tabular}{|l|c|c|c|c|}
\hline & $\mathbf{C d}$ & $\mathbf{C u}$ & $\mathbf{N i}$ & $\mathbf{P b}$ \\
\hline Natalspruit & $1.2 \pm 0.94$ & $32.8 \pm 13.2 *$ & $6.4 \pm 1.6$ & $6.6 \pm 2.1$ \\
wetlands & $\begin{array}{c}78.3 \% \\
\mathrm{n}=18\end{array}$ & $\begin{array}{c}40.2 \% \\
26.2 \%\end{array}$ & $\begin{array}{c}31.8 \% \\
3.8-9.5\end{array}$ & $3.5-11.3$ \\
\hline Marievale & $1.3 \pm 0.51$ & $21.2 \pm 10.8$ & $5.4 \pm 1.0$ & $5.8 \pm 1.8$ \\
wetlands & $39.2 \%$ & $50.0 \%$ & $18.5 \%$ & $31.0 \%$ \\
$\mathrm{n}=20$ & $0.48-2.5$ & $6.9-51.2$ & $3.7-7.5$ & $2.7-9.9$ \\
\hline Germiston & $2.2 \pm 1.3$ & $26.8 \pm 7.8$ & $6.5 \pm 1.8$ & $14.1 \pm 4.0$ \\
Lake & $59.1 \%$ & $29.1 \%$ & $27.7 \%$ & $28.4 \%$ \\
$\mathrm{n}=9$ & $0.71-4.6$ & $13.4-35.3$ & $4.3-10.1$ & $9.7-20.2$ \\
\hline Florida & $0.71 \pm 0.13$ & $13.1 \pm 8.0$ & $5.8 \pm 1.8$ & $8.5 \pm 2.7$ \\
Lake & $18.3 \%$ & $61.1 \%$ & $31.0 \%$ & $31.8 \%$ \\
$\mathrm{n}=15$ & $0.54-0.97$ & $6.9-32.7$ & $4.0-9.2$ & $5.6-14.4$ \\
\hline Steynsrus & $0.77 \pm 0.19$ & $30.2 \pm 14.6$ & $5.1 \pm 1.2$ & $6.3 \pm 1.6$ \\
farm dams & $24.7 \%$ & $48.3 \%$ & $23.5 \%$ & $25.4 \%$ \\
$\mathrm{n}=21$ & $0.45-1.2$ & $15.4-84.6$ & $3.4-7.9$ & $3.5-9.8$ \\
\hline *n=17 & \multicolumn{4}{|l}{} \\
\hline
\end{tabular}

TABLE 3

Concentrations ( $\mu \mathrm{g} / \mathrm{g}$ dry mass) of metals in kidney from five Redknobbed Coot populations. Results are given as $\bar{x} \pm S D$, coefficient of variation (\%) and range (minimum - maximum)

\begin{tabular}{|c|c|c|c|c|}
\hline & $C d$ & $\mathrm{Cu}$ & $\mathrm{Ni}$ & $\mathrm{Pb}$ \\
\hline $\begin{array}{l}\text { Natalspruit } \\
\text { wetlands } \\
n=18\end{array}$ & $\begin{array}{c}2.3 \pm 1.4^{1} \\
60.9 \% \\
1.0-6.5\end{array}$ & $\begin{array}{c}25.1 \pm 8.4 \\
33.5 \% \\
16.7-49.2\end{array}$ & $\begin{array}{c}12.4 \pm 4.5 \\
36.3 \% \\
6.7-26.6\end{array}$ & $\begin{array}{c}8.9 \pm 5.6 \\
62.9 \% \\
4.9-30.0\end{array}$ \\
\hline $\begin{array}{l}\text { Marievale } \\
\text { wetlands } \\
n=20\end{array}$ & $\begin{array}{c}6.4 \pm 3.6 \\
56.3 \% \\
1.8-14.9\end{array}$ & $\begin{array}{c}17.9 \pm 4.4^{2} \\
24.6 \% \\
9.6-26.6\end{array}$ & $\begin{array}{c}12.5 \pm 3.7 \\
29.6 \% \\
7.7-21.2\end{array}$ & $\begin{array}{c}13.7 \pm 13.8^{1} \\
100.7 \% \\
6.0-62.2\end{array}$ \\
\hline $\begin{array}{l}\text { Germiston } \\
\text { Lake } \\
n=9\end{array}$ & $\begin{array}{c}5.4 \pm 4.6 \\
85.2 \% \\
0.75-15.2\end{array}$ & $\begin{array}{c}20.4 \pm 2.7 \\
13.2 \% \\
16.1-25.7\end{array}$ & $\begin{array}{c}10.1 \pm 3.3 \\
32.7 \% \\
6.5-16.4\end{array}$ & $\begin{array}{c}19.5 \pm 8.4 \\
43.1 \% \\
10.7-32.1\end{array}$ \\
\hline $\begin{array}{l}\text { Florida } \\
\text { Lake } \\
\mathrm{n}=15\end{array}$ & $\begin{array}{c}2.1 \pm 0.55 \\
26.2 \% \\
1.1-3.0\end{array}$ & $\begin{array}{c}15.3 \pm 4.3 \\
28.1 \% \\
8.7-22.2\end{array}$ & $\begin{array}{c}8.8 \pm 2.8 \\
26.1 \% \\
5.8-14.1\end{array}$ & $\begin{array}{c}9.5 \pm 2.2 \\
28.2 \% \\
5.4-13.9\end{array}$ \\
\hline $\begin{array}{l}\text { Steynsrus } \\
\text { farm dams } \\
n=21\end{array}$ & $\begin{array}{c}1.9 \pm 0.71 \\
37.4 \% \\
1.0-3.9\end{array}$ & $\begin{array}{c}20.8 \pm 4.5 \\
21.6 \% \\
13.2-33.4\end{array}$ & $\begin{array}{c}11.5 \pm 4.7 \\
40.9 \% \\
5.7-26.1\end{array}$ & $\begin{array}{c}16.5 \pm 19.9^{3} \\
120.6 \% \\
4.4-85.6\end{array}$ \\
\hline${ }^{1} \mathrm{n}=17 ;{ }^{2} \mathrm{n}=$ & & & & \\
\hline
\end{tabular}

checked for metal contamination during AAS analysis. The detection limits for the metals analysed were: $\mathrm{Cd}(0.002 \mu \mathrm{g} / \mathrm{m} \ell), \mathrm{Cu}(0.003 \mu \mathrm{g} / \mathrm{m} \ell), \mathrm{Ni}(0.01$ $\mu \mathrm{g} / \mathrm{m} \ell)$ and $\mathrm{Pb}(0.01 \mu \mathrm{g} / \mathrm{m} \ell)$. The mean of five instrument readings was taken for each sample. The metal concentrations were determined in $\mathrm{mg} / \ell$ by AAS. These values were recalculated using the following formula:

AAS reading $\div 10=\mathrm{mg} / 100 \mathrm{~m} \ell \div$ digested mass $=\mathrm{mg} / \mathrm{g} \times 1000=\mu \mathrm{g} / \mathrm{g}$

and the calculated data expressed as $\mu \mathrm{g} / \mathrm{g}$ dry mass (d.m.).

The results of this investigation were summarised by determining the minimum and maximum metal concentration values and by calculating a mean concentration value for each data set. Any concentration value that was larger than $\overline{\mathrm{x}}+2 \mathrm{SD}$ was not included for statistical analysis. The results were also summarised by calculating the standard deviation (SD) and the coefficient of variation $(\mathrm{CV})$. For this investigation, the coefficient of variation $(\mathrm{CV} \%)$ was used to indicate the variability in metal levels, which can also be related to the bird's ability to regulate the level of a metal in a specific organ or tissue, with higher percentage values suggesting either an inadequate regulation ability or a naturally high variability in metal content (Muirhead and Furness, 1988).

Selected statistical methods were also used to determine the possible significance of the results. All the data were collected on a completely random basis, the data sets did not have a normal distribution and the population variances were heterogeneous due to the unequal sample sizes. In view of these factors, use was made of the non-parametric analysis of variance by ranks method namely the KruskalWallis Test(Zar, 1974; Hassard, 1991). However, the rejection of the null hypothesis by the KruskalWallis Test does not imply that all the mean metal concentrations were different from one another. In order to locate that mean value that did differ from others within the same group, the alternate hypothesis was tested with the multiple comparison method namely the Newman-Keuls Test (Zar, 1974; Hassard, 1991). The significance level used throughout this test was $\mathrm{p}<0.05$. The statistical analysis was conducted using the KwikStat ShareWare Package distributed by TexaSoft.

\section{Results}

\section{Geographical variations in organ and tissue metal concentrations}

\section{Liver}

The livers of coot from Germiston Lake had the highest concentrations of $\mathrm{Cd}, \mathrm{Ni}$ and $\mathrm{Pb}$ (Table 2). The highest $\mathrm{Cu}$ value was obtained from coots collected at the Natalspruit wetlands. The lowest values for the individual metals were shared among the coots sampled from the Florida Lake $(\mathrm{Cd}, \mathrm{Cu})$, 
Steynsrus farm dams (Ni) and Marievale wetlands $(\mathrm{Pb})$. Although variations $(\mathrm{CV} \%)$ in metal concentrations within sample localities were relatively large, especially in the case of liver $\mathrm{Ni}$ and $\mathrm{Cd}$ (Table 2), differences in liver metal concentrations among the different localities were relatively small (Fig. 1). Even though the Cd concentrations were small, the recorded values had a wide range, especially in the cases of those coots sampled from the Germiston Lake and Natalspruit wetlands (Table 2).

\section{Kidney}

The highest metal concentrations were detected in coots from the Marievale wetlands $(\mathrm{Cd}, \mathrm{Ni})$, the Germiston Lake $(\mathrm{Pb})$ and the Natalspruit wetlands $(\mathrm{Cu})($ Table 3$)$. The lowest values for the four metals were shared among the Florida Lake $(\mathrm{Cu}, \mathrm{Ni})$, the Steynsrus farm dams (Cd) and the Natalspruit wetlands $(\mathrm{Pb})$. The variation (CV\%) among sampling localities was moderate for $\mathrm{Ni}(26 \%-41 \%)$ and $\mathrm{Cu}$ (13\%-34\%) (Table 3; Fig. 1). Large variations in the $\mathrm{Cd}$ concentrations in coots from the Natalspruit wetlands $(61 \%)$ and the Germiston Lake $(85 \%)$ as well as in $\mathrm{Pb}$ concentrations in coots from the Marievale wetlands (101\%) and the Steynsrus farm dams $(121 \%)$ resulted in a high degree of variation for these specific metals between the five different localities (Table 3 and Fig. 1).

\section{Bone}

The highest metal concentrations were detected in coots from the Natalspruit wetlands $(\mathrm{Cd}, \mathrm{Ni})$, the Germiston Lake $(\mathrm{Pb})$ and the Steynsrus farm dams
(Cu) (Table 4). The lowest values for the four metals were detected in samples from the Germiston Lake $(\mathrm{Cd}, \mathrm{Cu})$ and the Marievale wetlands $(\mathrm{Ni}, \mathrm{Pb})$. Relatively small variations (CV\%) in $\mathrm{Pb}$ content, ranging from $10 \%$ to $32 \%$, were found among the five localities. However, substantially smaller variations in the concentrations of the other three metals were detected among the different sampling localities, ranging

TABLE 4

Concentrations ( $\mu \mathrm{g} / \mathrm{g}$ dry mass) of metals in bone from five Redknobbed Coot populations. Results are given as $\bar{x} \pm$ SD, coefficient of variation (\%) and range (minimum - maximum)

\begin{tabular}{|c|c|c|c|c|}
\hline & $C d$ & $\mathrm{Cu}$ & $\mathrm{Ni}$ & $\mathrm{Pb}$ \\
\hline $\begin{array}{l}\text { Natalspruit } \\
\text { wetlands } \\
n=18\end{array}$ & $\begin{array}{c}4.8 \pm 0.57 \\
11.9 \% \\
3.8-6.0\end{array}$ & $\begin{array}{c}5.5 \pm 1.2 \\
21.8 \% \\
4.3-9.4\end{array}$ & $\begin{array}{c}23.8 \pm 3.4 \\
14.3 \% \\
17.7-29.3\end{array}$ & $\begin{array}{c}30.1 \pm 4.1 \\
13.6 \% \\
22.4-38.1\end{array}$ \\
\hline $\begin{array}{l}\text { Marievale } \\
\text { wetlands } \\
n=20\end{array}$ & $\begin{array}{c}4.2 \pm 0.58 \\
13.8 \% \\
3.1-5.5\end{array}$ & $\begin{array}{c}5.0 \pm 0.50 \\
10.0 \% \\
4.2-6.3\end{array}$ & $\begin{array}{c}20.6 \pm 2.6 \\
12.6 \% \\
15.9-26.9\end{array}$ & $\begin{array}{c}26.8 \pm 2.8 \\
10.4 \% \\
20.9-32.1\end{array}$ \\
\hline $\begin{array}{l}\text { Germiston } \\
\text { Lake } \\
n=9\end{array}$ & $\begin{array}{c}0.86 \pm 0.10 \\
2.3 \% \\
0.72-1.0\end{array}$ & $\begin{array}{c}4.9 \pm 0.40 \\
8.2 \% \\
4.5-5.6\end{array}$ & $\begin{array}{c}22.1 \pm 2.8 \\
12.7 \% \\
18.4-27.6\end{array}$ & $\begin{array}{c}44.8 \pm 14.1 \\
31.5 \% \\
26.4-64.1\end{array}$ \\
\hline $\begin{array}{l}\text { Florida } \\
\text { Lake } \\
\mathrm{n}=15\end{array}$ & $\begin{array}{c}4.4 \pm 0.55 \\
12.5 \% \\
3.6-5.8\end{array}$ & $\begin{array}{c}5.2 \pm 0.60 \\
11.5 \% \\
4.2-6.9\end{array}$ & $\begin{array}{c}22.0 \pm 2.8 \\
12.7 \% \\
17.9-29.7\end{array}$ & $\begin{array}{c}29.6 \pm 4.3 \\
14.1 \% \\
23.7-38.8\end{array}$ \\
\hline $\begin{array}{l}\text { Steynsrus } \\
\text { farm dams } \\
\mathrm{n}=21\end{array}$ & $\begin{array}{c}4.6 \pm 0.84 \\
18.3 \% \\
3.5-6.6\end{array}$ & $\begin{array}{c}5.6 \pm 0.89 \\
15.9 \% \\
4.4-7.2\end{array}$ & $\begin{array}{c}21.9 \pm 4.1 \\
18.7 \% \\
16.6-33.4\end{array}$ & $\begin{array}{c}28.2 \pm 3.8 \\
13.5 \% \\
23.1-35.9\end{array}$ \\
\hline
\end{tabular}
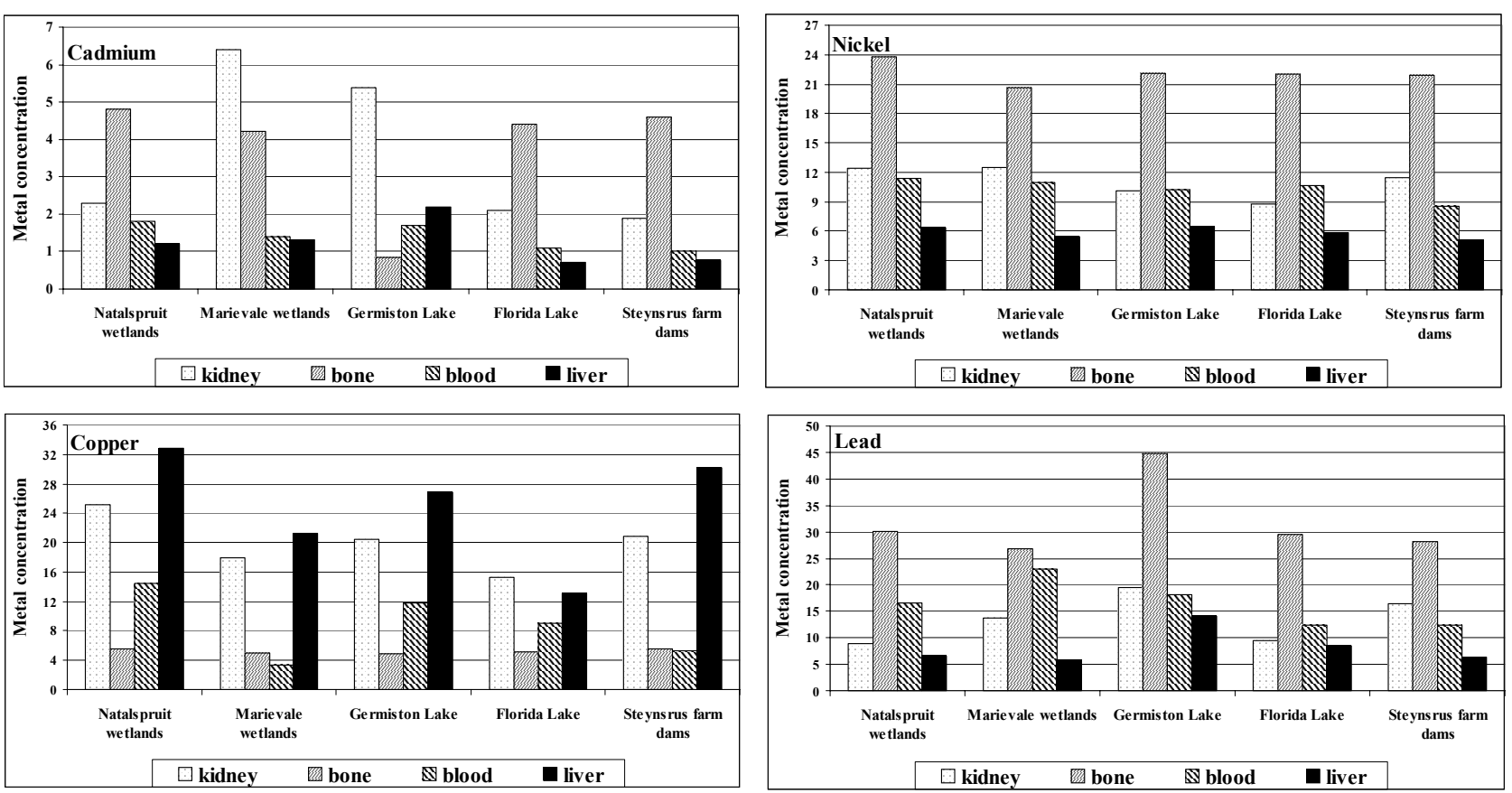

Figure 1

The mean concentrations (expressed as $\mu \mathrm{g} / \mathrm{g}$ dry mass) of $\mathrm{Cd}, \mathrm{Cu}, \mathrm{Ni}$ and $\mathrm{Pb}$ in organs and tissues of five Red-knobbed Coot populations sampled from the Natalspruit wetlands, Marievale wetlands, Germiston Lake, Florida Lake and Steynsrus farm dams 


\begin{tabular}{|c|c|c|c|c|}
\hline \multicolumn{5}{|c|}{$\begin{array}{l}\text { TABLE } 5 \\
\text { Concentrations ( } \mu \mathrm{g} / \mathrm{g} \text { dry mass) of metals in blood from five Red- } \\
\text { knobbed Coot populations. Results are given as } \bar{x} \pm \text { SD, coefficient } \\
\text { of variation ( } \% \text { ) and range (minimum - maximum) }\end{array}$} \\
\hline & $\mathrm{Cd}$ & $\mathrm{Cu}$ & $\mathrm{Ni}$ & $\mathrm{Pb}$ \\
\hline $\begin{array}{l}\text { Natalspruit } \\
\text { wetlands } \\
\mathrm{n}=18\end{array}$ & $\begin{array}{c}1.8 \pm 0.97 \\
53.9 \% \\
1.0-4.8\end{array}$ & $\begin{array}{l}14.4 \pm 10.9 \\
75.7 \% \\
4.3-44.4\end{array}$ & $\begin{array}{l}11.4 \pm 7.0 \\
61.4 \% \\
5.7-33.3\end{array}$ & $\begin{array}{l}16.6 \pm 15.5^{*} \\
93.4 \% \\
7.1-61.1\end{array}$ \\
\hline $\begin{array}{l}\text { Marievale } \\
\text { wetlands } \\
\mathrm{n}=20\end{array}$ & $\begin{array}{l}1.4 \pm 0.48 \\
34.3 \% \\
0.66-2.2\end{array}$ & $\begin{array}{l}3.4 \pm 1.4 \\
41.2 \% \\
1.3-7.3\end{array}$ & $\begin{array}{c}10.9 \pm 4.0 \\
36.7 \% \\
3.8-17.4\end{array}$ & $\begin{array}{c}23.0 \pm 6.4^{*} \\
27.8 \% \\
9.1-37.5\end{array}$ \\
\hline $\begin{array}{l}\text { Germiston } \\
\text { Lake } \\
n=9\end{array}$ & $\begin{array}{c}1.7 \pm 1.3 \\
76.5 \% \\
0.71-4.9\end{array}$ & $\begin{array}{c}11.8 \pm 8.8 \\
74.6 \% \\
3.0-32.4\end{array}$ & $\begin{array}{c}10.2 \pm 7.7 \\
75.5 \% \\
4.5-29.7\end{array}$ & $\begin{array}{c}18.1 \pm 6.8 \\
37.6 \% \\
10.2-32.4\end{array}$ \\
\hline $\begin{array}{l}\text { Florida } \\
\text { Lake } \\
\mathrm{n}=15\end{array}$ & $\begin{array}{c}1.1 \pm 0.44 \\
40.4 \% \\
0.63-2.1\end{array}$ & $\begin{array}{c}9.1 \pm 7.9 \\
86.8 \% \\
2.8-30.6\end{array}$ & $\begin{array}{c}10.6 \pm 4.6 \\
43.4 \% \\
3.8-20.7\end{array}$ & $\begin{array}{c}12.3 \pm 4.0 \\
32.5 \% \\
8.6-19.4\end{array}$ \\
\hline $\begin{array}{l}\text { Steynsrus } \\
\text { farm dams } \\
n=21\end{array}$ & $\begin{array}{c}1.0 \pm 0.49 \\
49.0 \% \\
0.43-2.2\end{array}$ & $\begin{array}{c}5.3 \pm 3.4 \\
64.2 \% \\
2.6-17.4\end{array}$ & $\begin{array}{c}8.6 \pm 5.3 \\
61.6 \% \\
3.2-25.9\end{array}$ & $\begin{array}{c}12.3 \pm 5.5 \\
44.7 \% \\
6.1-25.9\end{array}$ \\
\hline \multicolumn{5}{|l|}{$*_{\mathrm{n}}=14$} \\
\hline
\end{tabular}

and blood and for $\mathrm{Cu}, \mathrm{Ni}$ and $\mathrm{Pb}$. The statistical evaluation of the data indicated that in all cases real geographical differences existed in the metal concentrations in the five coot populations (Table 6). The statistical analysis also provided evidence that in most cases (13 out of 16) metal concentrations in coots from the Steynsrus farm dams, which was chosen as the reference site anticipated to be only slightly polluted, did not differ significantly from the four Gauteng Province localities, which are known to contain relatively large concentrations of the four metals, especially $\mathrm{Cu}, \mathrm{Pb}$ and $\mathrm{Ni}$. Thus, the metal values obtained for the organs and tissues of the coots from the Steynsrus farm dams cannot be said to represent background or natural concentrations of the four metals concerned.

No clear trend was found concerning the degree of metal pollution in the five localities. For instance, the Kruskal-Wallis analysis of variance test indicated that comparatively little variation $(\mathrm{H}=6.86)$ existed in the bone $\mathrm{Cu}$ concentrations among the five localities (range $=4.9$ to $5.6 \mu \mathrm{g}$ $\mathrm{Cu} / \mathrm{g}$ ), yet the Newman-Keuls multiple comparison test indicated that these mean $\mathrm{Cu}$ concentrations differed significantly $(\mathrm{p}<0.05)$ among the five localities (Table 6). Thus, no significant distinction was found among coots from the more seriously polluted localities and coots from a site which experiences slight agricultural pollution.

from a low of $2 \%$ (Cd from Germiston Lake) to a high of $22 \%(\mathrm{Cu}$ from Natalspruit wetlands) (Table 4 and Fig. 1).

\section{Blood}

The highest metal concentrations were detected in coots from the Natalspruit wetlands $(\mathrm{Cd}, \mathrm{Cu}, \mathrm{Ni})$ and Marievale wetlands $(\mathrm{Pb})($ Table 5). The lowest values for the four metals were shared between coots from the Steynsrus farm dams $(\mathrm{Cd}, \mathrm{Ni})$, the Florida Lake $(\mathrm{Pb})$ and the Marievale wetlands $(\mathrm{Cu})$. The variation $(\mathrm{CV} \%)$ among the five sampling localities was relatively large (Fig. 1), especially in the case of $\mathrm{Pb}(28 \%-93 \%)$ and to a lesser extent $\mathrm{Cd}$ (34\%-77\%) and $\mathrm{Cu}(41 \%-87 \%$; Table 5).

A few individual organ and tissue samples contained metal concentrations that were found to be exceptionally high and which exceeded the $\bar{x}+2 \mathrm{SD}$. These values were excluded from the data as well as from the results used during the statistical evaluation thereof. For instance, one particular liver sample had a Cu content of 195.8 $\mu \mathrm{g} / \mathrm{g}$ whilst a few kidney samples analysed had values of $30.0 \mu \mathrm{g}$ $\mathrm{Cd} / \mathrm{g}, 74.8 \mu \mathrm{g} \mathrm{Cu} / \mathrm{g}$ and 223.1, 131.2,370.3 and $223.3 \mu \mathrm{g} \mathrm{Pb} / \mathrm{g}$. Some of the blood samples contained exceptionally high concentrations of $\mathrm{Pb}(290.9 ; 161.2 ; 273.2 ; 116.0 ; 242.6 ; 54.8 ; 93.0 ; 58.0 ; 107.2$ and $108.5 \mu \mathrm{g} / \mathrm{g}$ ). These relatively high metal values found in these samples, especially that for $\mathrm{Pb}$, may indicate that some of the coots were either naturally more contaminated by metals than were the majority of the coots or more likely that it was due to gunshot contamination. However, the precise reasons for this phenomenon are not known.

\section{Statistical analysis of the geographical variations in organ and tissue metal concentrations}

In Fig. 1 it can be seen that distinct geographical trends occurred for most organs and metals, especially in the cases of the liver, kidney

\section{Discussion}

Little information is available on the ability of coots (Fulica spp.) to accumulate metals from the aquatic environment. For single specimens of the American Coot (F. americana), wet mass (w.m.) $\mathrm{Pb}$ concentrations of $2 \mu \mathrm{g} / \mathrm{g}$ in the liver and $3 \mu \mathrm{g} / \mathrm{g}$ in the tibia (Bagley and Locke, 1967) and $2 \mu \mathrm{g} / \mathrm{g}$ in the kidney (Anderson, 1975) have been recorded. Data (w.m.) for the Red-knobbed Coot found in this study (liver 1-3 $\mu \mathrm{g} / \mathrm{g}$; kidney 2-3 $\mu \mathrm{g} / \mathrm{g}$; bone $24-38 \mu \mathrm{g} / \mathrm{g}$ ) (refer to Table 1 for percentage moisture content in order to facilitate conversions to w.m.) compared well with the studies of Bagley and Locke (1967) and Anderson (1975). The mean dry mass (d.m.) Pb concentrations of $6 \mu \mathrm{g} / \mathrm{g}$ in the liver, $14 \mu \mathrm{g} / \mathrm{g}$ in the kidney and $39 \mu \mathrm{g} /$ $\mathrm{g}$ in the sacral vertebrae of Red-knobbed Coots collected from the Natalspruit wetlands during 1989 (Van Eeden and Schoonbee, 1992) also compared well with the results obtained for coots collected during this study (1991/1992: Tables 2 to 5). This would suggest that the Red-knobbed Coots collected from the five localities were most likely exposed to chronic low levels of $\mathrm{Pb}$ toxicity in the Natalspruit wetland in particular(VanEeden and Schoonbee, 1992), but also to some extent in the other aquatic environments sampled during this investigation. A very high w.m. metal value of $73 \mu \mathrm{g}$ $\mathrm{Pb} / \mathrm{g}$ in the liver of an American Coot was recorded by Anderson (1975), which would indicate that this specimen was possibly exposed to acute rather than chronic $\mathrm{Pb}$ toxicity (Scheuhammer, 1987).

White et al. (1986) conducted a comprehensive study on metal concentrations in organs and tissues of the American Coot. Over a period of three years, they compared the w.m. concentrations of several metals in coots from a control site with those from a pond contaminated by a power plant. For the control site, the maximum metal levels observed by these authors were $15 \mu \mathrm{g} \mathrm{Cu} / \mathrm{g}, 1 \mu \mathrm{g} \mathrm{Ni} / \mathrm{g}$ and $0.6 \mu \mathrm{g} \mathrm{Cd} / \mathrm{g}$ in the liver and $6 \mu \mathrm{g} \mathrm{Pb} / \mathrm{g}$ in the femur. For the polluted 


\begin{tabular}{|c|c|c|c|c|c|c|c|}
\hline \multicolumn{8}{|c|}{$\begin{array}{c}\text { TABLE } 6 \\
\text { Analysis of variance }(\mathrm{H}) \text { and multiple comparisons analysis of the variations in concentrations of } \\
\text { four metals in selected organs and tissues of the Red-knobbed Coot from five geographically } \\
\text { different localities. Mean metal concentrations within a row sharing a common superscript are } \\
\text { not significantly different at the } p<0.05 \text { level of significance }\end{array}$} \\
\hline \multirow{2}{*}{$\begin{array}{l}\text { Organ/ } \\
\text { Tissue }\end{array}$} & \multirow{2}{*}{$\begin{array}{c}\text { Metal } \\
\mathrm{Cd}\end{array}$} & \multirow{2}{*}{$\begin{array}{c}\text { H-value } \\
26.37\end{array}$} & \multicolumn{5}{|c|}{ Locality and mean metal concentration } \\
\hline & & & NW $1.2^{\mathrm{a}}$ & MW $1.3^{\mathrm{b}}$ & $\mathrm{GL} 2.2^{\mathrm{c}}$ & $\mathrm{FL} \quad 0.71^{\mathrm{d}}$ & SR $0.77 \mathrm{e}$ \\
\hline Liver & $\mathrm{Cu}$ & 26.86 & NW 32.8 & MW 21.2 ${ }^{\mathrm{b}}$ & GL $26.8^{c}$ & SR $30.2^{c}$ & FL $13.1^{\mathrm{d}}$ \\
\hline Liver & $\mathrm{Ni}$ & 8.47 & NW $6.4^{\mathrm{a}}$ & SR $5.1^{\mathrm{b}}$ & MW $5.4^{\mathrm{c}}$ & GL $6.5^{\mathrm{c}}$ & FL $5.8^{\mathrm{c}}$ \\
\hline Liver & $\mathrm{Pb}$ & 29.08 & NW $6.6^{\mathrm{a}}$ & SR $6.3^{\mathrm{a}}$ & MW $5.8^{\mathrm{b}}$ & GL $14.1^{\mathrm{c}}$ & FL $9.7^{\mathrm{d}}$ \\
\hline Kidney & $\mathrm{Cd}$ & 12.30 & $\mathrm{NW} 2.3^{\mathrm{a}}$ & FL 2.1 $1^{\mathrm{a}}$ & MW $6.4^{b}$ & GL $5.4^{\mathrm{c}}$ & SR $1.9^{\mathrm{d}}$ \\
\hline Kidney & $\mathrm{Cu}$ & 23.31 & SR $20.8^{\mathrm{a}}$ & GL $20.4^{\mathrm{a}}$ & NW 25.1 ${ }^{\mathrm{b}}$ & MW $17.9^{c}$ & FL $15.3^{\mathrm{d}}$ \\
\hline Kidney & $\mathrm{Ni}$ & 13.62 & $\mathrm{NW} 12.4^{\mathrm{a}}$ & MW $12.5^{\mathrm{a}}$ & GL $10.1^{\mathrm{b}}$ & FL $8.8^{c}$ & SR $11.5^{\mathrm{d}}$ \\
\hline Kidney & $\mathrm{Pb}$ & 17.09 & NW 8.9 & MW $13.7^{b}$ & FL $9.5^{b}$ & SR $16.5^{b}$ & GL $19.5^{\mathrm{c}}$ \\
\hline Bone & $\mathrm{Cd}$ & 31.26 & NW 4.8 & $\mathrm{MW} 4.2^{\mathrm{b}}$ & GL $0.86^{\mathrm{c}}$ & FL $4.4 d$ & SR $4.6^{\mathrm{e}}$ \\
\hline Bone & $\mathrm{Cu}$ & 6.86 & NW $5.5^{\mathrm{a}}$ & MW 5.0 & $\mathrm{GL} 4.9^{\mathrm{c}}$ & FL $5.2 d$ & SR $5.6^{\mathrm{e}}$ \\
\hline Bone & $\mathrm{Ni}$ & 9.49 & NW $23.8^{\mathrm{a}}$ & MW $20.6^{\mathrm{b}}$ & GL $22.1^{\mathrm{c}}$ & FL $22.0^{c}$ & SR $21.9^{c}$ \\
\hline Bone & $\mathrm{Pb}$ & 21.15 & NW 30.1 $1^{\mathrm{a}}$ & FL 29.6 $6^{\mathrm{a}}$ & MW $26.8^{b}$ & GL $44.8^{c}$ & SR $28.2^{\mathrm{d}}$ \\
\hline Blood & $\mathrm{Cd}$ & 12.41 & NW $1.8^{\mathrm{a}}$ & MW $1.4^{\mathrm{b}}$ & GL $1.7^{\mathrm{b}}$ & $\mathrm{FL} 1.1^{\mathrm{c}}$ & SR $1.0^{\mathrm{d}}$ \\
\hline Blood & $\mathrm{Cu}$ & 37.83 & $\mathrm{NW} 14.4^{\mathrm{a}}$ & MW 3.4 & GL $11.8^{c}$ & FL 9.1d & SR $5.3^{\mathrm{e}}$ \\
\hline Blood & $\mathrm{Ni}$ & 5.64 & NW 11.4 $4^{\mathrm{a}}$ & FL $10.6^{\mathrm{a}}$ & MW 10,9a & GL $10.2^{b}$ & SR $8.6^{\mathrm{b}}$ \\
\hline Blood & $\mathrm{Pb}$ & 22.92 & NW $16.6^{\mathrm{a}}$ & $\mathrm{FL} 12.3^{\mathrm{a}}$ & SR $12.3^{a}$ & GL $18.1^{b}$ & MW 23.0 \\
\hline
\end{tabular}

pond site, the maximum metal levels found were $36 \mu \mathrm{g} \mathrm{Cu} / \mathrm{g}, 4 \mu \mathrm{g}$ $\mathrm{Ni} / \mathrm{g}$ and $2 \mu \mathrm{g} \mathrm{Cd} / \mathrm{g}$ in the liver and $3 \mu \mathrm{g} \mathrm{Pb} / \mathrm{g}$ in the femur. The data of White et al. (1986) compare well with the w.m. (converted) liver $\mathrm{Ni}$ and $\mathrm{Cd}$ concentrations found in the Red-knobbed Coot of the present study ( 1 to $2 \mu \mathrm{g} \mathrm{Ni} / \mathrm{g} ; 0.2$ to $0.5 \mu \mathrm{g} \mathrm{Cd} / \mathrm{g}$ ). However, their w.m. liver $\mathrm{Cu}$ levels found were 2 to 3 times higher while their w.m. bone $\mathrm{Pb}$ levels were at least four times lower compared to the results (liver $=3$ to $8 \mu \mathrm{g} \mathrm{Cu} / \mathrm{g}$; bone $=24$ to $38 \mu \mathrm{g} \mathrm{Pb} / \mathrm{g}$ ) of this investigation. These particular results may indicate that the Red-knobbed Coots were exposed to elevated $\mathrm{Pb}$ contamination, most probably due to anthropogenic activities. The elevated $\mathrm{Cu}$ levels in the liver of the coots analysed by White et al. (1986) may perhaps be related to some functional aspect of the power plant, e.g. the use of $\mathrm{Cu}-$ containing biocides.

Carpené et al. (1990) recorded w.m. concentrations of $6 \mu \mathrm{g} \mathrm{Cu} /$ $\mathrm{g}$ in the liver as well as $3 \mu \mathrm{g} \mathrm{Cu} / \mathrm{g}$ and $0.4 \mu \mathrm{g} \mathrm{Cd} / \mathrm{g}$ in the kidneys of an unknown number of European Coot $(F$. atra) samples collected from an unknown locality. Kreuzer and Wissmath (1976) recorded w.m. concentrations of approximately $0.2 \mu \mathrm{g} \mathrm{Cd} / \mathrm{g}$ and $1 \mu \mathrm{g} \mathrm{Pb} / \mathrm{g}$ in the liver as well as $0.2 \mu \mathrm{g} \mathrm{Cd} / \mathrm{g}$ and $1 \mu \mathrm{g} \mathrm{Pb} / \mathrm{g}$ in the kidneys of eight European Coot specimens from differently polluted areas in Bavaria, Germany. These metal concentrations compare well with those found for this investigation on F. cristata (Tables 2-5).

Hernández et al. (1999) recorded dry mass concentrations of $0.42 \mu \mathrm{g}$ for $\mathrm{Cd}$ and $47.3 \mu \mathrm{g}$ for $\mathrm{Cu}$ in the liver of a single $F$. atra specimen collected prior to 1992 in the Donana National Park, Spain. Again, these results compare well with those found for this investigation (Table 2). However, during the course of 1998, European
Coots and other aquatic birds were exposed to very high levels of metals after metal-containing mining wastes entered the Park after the collapse of a tailings dam from the Aznalcollar mine. During this period of high exposure, dry mass $\mathrm{Cd}$ (nd to $0.86 \mu \mathrm{g}$ ) and $\mathrm{Pb}$ (nd to $8.7 \mu \mathrm{g}$ ) ranges from $24 \mathrm{~F}$. atra livers (Hernández et al., 1999) still compare well with those found during this investigation (Table 2). However, $\mathrm{Cu}$ levels increased dramatically to a mean value of $149.9 \mu \mathrm{g}(12.6$ to $498.3 \mu \mathrm{g})$, which is at least five times higher than that recorded during this study.

Hui (1998) reported on the dry mass concentrations of 18 metals and arsenic (As) in 39 livers of American Coots collected from four sites in the San Francisco Bay area. Values recorded for Cd (up to $1.6 \pm 1.1 \mu \mathrm{g}$ ) were similar to values reported here (Table 2) whilst results for $\mathrm{Ni}$ (up to $1.6 \pm 1.6 \mu \mathrm{g}$ ) and $\mathrm{Pb}$ (up to $3.9 \pm 3.3 \mu \mathrm{g}$ ) were at least twice lower than those found during this study (Table 2). Similar to the Doñana National Park results, $\mathrm{Cu}$ (up to $70.0 \pm 13.2 \mu \mathrm{g}$ ) was again at least twice as high in American Coots (Hui, 1998) as in coots collected for this study.

Of the four metals studied in the present investigation, $\mathrm{Cd}$ occurred in the smallest concentration in the liver, blood, kidney and bone. Kidney Cd levels exceeded liver Cd levels by a factor of 2 to 5 (Tables 2 and 3). Similar trends were also recorded for other bird species (Nicholson, 1981; Lock et al., 1992). Such a situation may indicate the existence of chronic low-level exposure to $\mathrm{Cd}$ in the five localities rather than acute Cd toxicity, which would result in higher Cd levels in the liver than in the kidney (Scheuhammer, 1987). Toxic effects ofCd only occur in humans and other mammals when kidney Cd levels reach about $100 \mu \mathrm{g} / \mathrm{g}$ w.w. (Scheuhammer, 1987). Thus, 
considering the indicator ability of the coot, it can be assumed that the current levels of Cd occurring in its organs and tissues in the five aquatic environments pose no real threat to the avifauna inhabiting these habitats for the time being.

From the available data it appears that comparatively large concentrations of the accumulated $\mathrm{Cd}, \mathrm{Ni}$ and $\mathrm{Pb}$ were stored in the bone of the coots which generally exceeded the liver $\mathrm{Cd}, \mathrm{Ni}$ and $\mathrm{Pb}$ levels by factors of 3-6, 3-4 and 3-5, respectively (Tables 2 and 4). Most of these metals, once physico-chemically bound in the bone matrix, may not be available for redistribution or excretion, and this may explain the relatively small variation found in the bone metal concentrations of the coots sampled from the five localities.

The coefficient of variation (CV\%) which was used to indicate the variability in metal concentrations can also be used to express the coot's ability to regulate the level of a metal in a specific organ or tissue, with higher percentage values suggesting either an inadequate regulation ability or a naturally high variability in body metal content (Muirhead and Furness, 1988). The results of the present study indicate that the metal concentrations bound in the bone, were best maintained, if not regulated, in the bone, where in all cases the variability was $<32 \%$ (Table 4 ). The liver and kidney (variability in most cases $<50 \%$ ) and the blood (variability in most cases $<70 \%$; Table 4) is similar to that for bone. Superficially, the results seem to indicate the presence of an inadequate ability to regulate the metal concentrations in the tissues and organs of the coot, most probably due to the available number (or lack thereof in the case of blood) of metal-binding sites (Chen and Ganther, 1975). This may result in possible hepatic and/or renal damage due to an excess of hepatic-and/ or renal-bound metals. Such a situation might be reflected in the relatively high variation found in metal concentrations in the liver and kidney. During a study on Laughing Gulls (Larus atricilla) from two Texas Gulf Coast bays, Reid and Hacker (1982) found that the $\mathrm{Pb}$ and $\mathrm{Cd}$ concentrations in selected organs and tissues of gulls from the rural, moderately industrialised bay region were lower than those recorded for gulls from the heavily industrialised and urbanised bay region. Similarly, White et al., (1986) found that the metal concentrations in the liver and femur of American Coots from a control site were generally lower compared to coots from a pond contaminated by a power plant. The fact that few significant differences were found between the organ metal concentrations of coots from the slightly polluted reference site and those from the polluted localities in the Gauteng Province (Table 6) would seem to suggest that the metal concentrations to which these coots were exposed, may be lower than their current tolerance levels for these particular metals. Thus, the metal variability found during this study may be ascribed to the naturally wide variation and general metabolic turnover in organ and tissue metal content, rather than to the metal levels to which the five coot populations were exposed in the actual, aquatic environments in which they occurred.

In aquatic birds, diet is most probably the major source of metal intake. It thus seems reasonable to conclude that the general trends in the dietary preferences of the five coot populations studied at the various localities might have an effect upon organ and tissue metal concentrations. Furthermore, the effects of diet might well be greater than mere geographic isolation in determining metal burdens. Hence, one could argue that one Red-knobbed Coot population might exhibit higher metal levels as a consequence of their specific diet rather than of any intrinsic function peculiar to the species of that particular geographic region. Numerous investigations have found that the trophic level, in connection with feeding habits and diet, was found to be the determining variable in the accumulation of a metal in a tissue (e.g. Van Eeden and Schoonbee, 1993; Hernández et al., 1999; Van Eeden, 2003).
One can also argue that the metal variability found in coots during this investigation might be due to the migratory and/or nomadic movement of coots. Even though some coot have been recorded to travel well over $1000 \mathrm{~km}$ (Underhill et al., 1999), no regular migration is known but it is a nomadic and opportunistic species (Taylor, 1997). Country-wide, coots normally concentrate on large permanent waters during dry seasons and then disperse to smaller permanent and temporary waters during the rainy seasons, mainly for breeding purposes (Taylor, 1997). However, models used to evaluate at least five years of atlassing data generated between 1987 and 1992 for coots over the whole of Southern Africa, did not reflect any movements and showed only minor seasonal fluctuations (Taylor, 1997). In fact, coots have actually increased both in abundance and range as the result of the construction of both small and large farm dams and impoundments (Underhill et al., 1999).

On a much smaller, regional scale, the existence of movements, or lack thereof, is clear from the coot numbers counted at individual wetlands. No fluctuations in coot numbers were recorded during five seasons at Marievale wetlands whilst coot numbers were always higher during winter counts versus summer counts at the Natalspruit wetlands (Taylor et al., 1999). These observations might be due to low water levels or to other drivers such as predation, flood events, lack of suitable sites or space for breeding purposes, humaninterference, lack of food and others. However, on a small geographic scale such as the Gauteng Province, these drivers might not be so significant at all since coots distribute and redistribute themselves between water bodies, mainly in response to water levels and amount of rainfall. Permanent wetlands, as well as impoundments, are frequented by coot as drought refuges and also as year-round breeding areas (Van Eeden, pers. observ.), especially since these water bodies are artificially kept at high water levels due to increasing surface water drainage and effluent discharge. Furthermore, the year-round availability of food, especially at sampling sites such as Germiston and Florida lakes that are frequented by large numbers of food-providing people, also influences the coots to stay at these water bodies. With the above in mind, it may be concluded that the majority of coots might indeed stay at one polluted dam/wetland with very limited migration taking place. The large number of statistically significant levels of variance found for metal and sampling site combinations (Table 5) supports this hypothesis. A coot-ringing project should be initiated to prove this hypothesis.

The aim of this investigation was to determine whether the Redknobbed Coot was able to assimilate and accumulate metals from their immediate surroundings, thus reflecting geographical trends. Although this was not always evident, some of the results of this investigation suggest that these particular approaches of biomonitoring, may well become a means of using the Red-knobbed Coot for the monitoring of pollution impacts in a distinct area (their home range) and over a period of time. Currently in South Africa there is comparatively little specific data on the effects of environmental pollution emanating from sewage purification works, industries, mines, agriculture and residential areas on aquatic habitats and the potential threat that these pollutants, especially metals, may have on the southern African aquatic avifauna. Therefore, the polluted streams, lakes and wetlands of the Witwatersrand and elsewhere in South Africa can serve as ideal field laboratories to assess this specific situation and to arrive at more definite conclusions and recommendations concerning the potential that some aquatic bird species, such as the Red-knobbed Coot, may have as bio-monitoring agents of the environment. 


\section{Acknowledgements}

I gratefully acknowledge all the support, guidance and friendship unselfishly provided by my mentor, ProfHJ Schoonbee (deceased). I also thank the Rand Afrikaans University for equipment and facilities provided as well as the Water Research Commission and the City of Germiston for financial support that made this study possible. The Cities of Germiston and Roodepoort are also thanked for permission to collect coots from the Germiston and Florida Lakes, respectively. The then Transvaal and Orange Free State Provincial Administrations granted the permits for collection of coots in the respective provinces. The constant support from $\mathrm{Mr}$ Dries Louw, as well as from Messrs Hennie Basson Snr. and Jnr. from the Vlakplaats Water Pollution Control Works is appreciated. I also thank Juan Viljoen and René Bredenkamp, as well as her parents, for much appreciated assistance and accommodation during the field collections of coots from the Steynsrus area.

\section{References}

ADENDORFF A (1992) Die Voorkoms van Geselekteerde Metale in Organe en Weefsels van die Kolgans Alopochen aegyptiacus en Waterhoender Gallinula chloropus in Myn-, Nywerheids- en Rioolbesoedelde Varswaterekosisteme aan die Witwatersrand. Unpublished M.Sc. thesis, Rand Afrikaans Univ., Johannesburg, $492 \mathrm{pp}$.

ADRIAN WJ and STEVENS ML (1979) Wet versus dry weights for heavy metal toxicity determinations in duck liver. J. Wildl. Diseases 15 125-126.

ANDERSON WL (1975) $\mathrm{Pb}$ poisoning in waterfowl at Rice Lake, Illinois. J. Wildl. Manage. 39 264-270.

BAGLEY GE and LOCKE LN (1967) The occurrence of $\mathrm{Pb}$ in tissues of wild birds. Bull. Environ. Contam. Toxicol. 2 297-305.

BEZUIDENHOUT LM, SCHOONBEE HJ and DE WET LPD (1990) Heavy metal content in organs of the African sharptooth catfish, Clarias gariepinus (Burchell), from a Transvaal lake affected by mine and industrial effluents. Part I. Zinc and Cu. Water SA 16 125129.

BULL KR, EVERY WJ, FREESTONE P, HALL JR and OSBORN D (1983) Alkyl $\mathrm{Pb}$ pollution and bird mortalities on the Mersey Estuary, UK, 1979-1981. Environ. Pollut. Ser. A 31 239-259.

CARPENÉ E, FEDRIZZI G, CORTESI P and CATTANI O (1990) Heavy metals $(\mathrm{Zn}, \mathrm{Cu}, \mathrm{Cd})$ in fish and aquatic birds. Ital. J. Biochem. 39 133A-134A.

CHEN RW and GANTHER HE (1975) Relative Cd-binding capacity of metallothionein and other cytosolic fractions in various tissues of the rat. Environ. Physiol. Biochem. 5 378-388.

DEPARTMENT OF WATER AFFAIRS (1986) Management of the Water Resources of the Republic of South Africa. Department of Water Affairs, Pretoria. 549 pp.

DE WET LPD (1990a) 'n Ekologiese Studie van die BlesbokspruitvleiEkosisteem aan die Oosrand met Spesiale Verwysing na die Besoedelingstoestande in die Cowles- en Nigeldamme. Unpublished M.Sc. Thesis, Rand Afrikaans Univ., Johannesburg. 390 pp.

DE WET LM (1990b) Akkumulering van Swaarmetale in " $n$ Myn- en Nywerheidsbesoedelde Meerekosisteem. Unpublished M.Sc. Thesis, Rand Afrikaans Univ., Johannesburg. 312 pp.

DE WET LM, SCHOONBEE HJ, DE WET LPD and WIID AJB (1994) Bioaccumulation of metals by the southern mouthbrooder, Psuedocrenilabrus philander (Weber, 1897) from a mine-polluted impoundment. Water SA 20 119-126.

DE WET LPD, SCHOONBEE HJ, PRETORIUS J and BEZUIDENHOUT LM (1990) Bioaccumulation of selected heavy metals by the water fern, Azolla filiculoides Lam. in a wetland ecosystem affected by sewage, mine and industrial pollution. Water $S A \mathbf{1 6}$ 281-286.

DOLAN J (1961) Water problems of the Transvaal and Orange Free State mines. In: Trans. of the 7th Commonwealth Mining and Metallurgical Congr. 3 1357-1388.
ELLENBERG H, DIETRICH J, STOEPPLER M and NÜRNBERG HW (1985) Environmental monitoring of heavy metals with birds as pollution integrating biomonitors. I. Introduction, definitions and practical examples for Goshawk (Accipiter gentilis). In: Lekkas. DT (ed.) Heavy Metals in the Environment, CEP Consultants Ltd., Edinburgh. 724-726.

FLEISCHER CL (1993) Bio-akkumulering van Metale in Organe en Weefsels van die Platanna Xenopus laevis in Myn- en Nywerheidsbesoedelde Varswaterekosisteme. Unpublished M.Sc. Thesis, Rand Afrikaans Univ., Johannesburg. 260 pp.

GREENWOOD NN and EARNSHAW A (1984) Chemistry of the Elements. Pergamon Press, New York. 1542 pp.

HASSARD TH (1991) Understanding Biostatistics. Mosby Pub., London. 300 pp.

HERNÁNDEZ LM, GÓMARA B, FERNÁNDEZ M, JIMÉNEZ B, GONZÁLEZ MJ, BAOS R, HIRALDO F, FERRER M, BENITO $\mathrm{V}$, SUÑER MA, DEVESA V, MUÑOZ O and MONTORO R (1999) Accumulation of heavy metals and As in wetland birds in the area around Doñana National Park affected by the Aznalcollar toxic spill. Sci. Tot. Environ. 242 293-308.

HUI CA (1998) Elemental contaminants in the livers and ingesta of four subpopulations of the American coot (Fulica americana): An herbivorous winter migrant in San Francisco Bay. Environ. Pollut. $101321-329$

JONES GA, BRIERLY SE, GELDENHUIS SJJ and HOWARD JR (1989) Research on the Contribution of Mine Dumps to the Mineral Pollution Load in the Vaal Barrage. WRC Rep. No. 136/ 1/89, Water Research Commission, Pretoria. 194 pp.

KEMPF C and SITTLER B (1977) La pollution de la zoocenose rhenane par le mercure et les produits organochlores. La Terre et la Vie 31 661-668 (in French).

KREUZER W and WISSMATH P (1976) Gehalte an schwermetallen $(\mathrm{Cd}$, blei, quecksilber) in einigen wildlebenden wasservogelarten. In: Wildlife Diseases, Proc. Third Int. Wildl. Dis. Conf. (1975), Plenum Press, New York. 301-315 (In German).

LOCK JW, THOMPSON DR, FURNESS RW and BARTLE JA (1992) Metal concentrations in seabirds of the New Zealand region. Environ. Pollut. 75 289-300.

MILES AK and TOME MW (1997) Spatial and temporal heterogeneity in metallic elements in industrialised aquatic bird habitats. Environ. Pollut. 95 75-84.

MUIRHEAD SJ and FURNESS RW (1988) Heavy metal concentrations in the tissues of seabirds from Gough Island, South Atlantic Ocean. Mar. Pollut. Bull. 19 278-283.

MUNOZ RV, HACKER CS and GESELL TF (1976) Environmentally acquired $\mathrm{Pb}$ in the Laughing Gull, Larus atricilla. J. Wildl. Dis. 12 139-143.

NICHOLSON JK (1981) The comparative distribution of zinc, Cd and mercury in selected tissues of the Herring Gull (Larus argentatus). Comp. Biochem. Physiol. 68C 91-94.

NYBØ S, FJELD PE, JERSTAD K and NISSEN A (1996) Long-range air pollution and its impact on heavy metal accumulation in dippers Cinclus cinclus in Norway. Environ. Pollut. 94 31-38

OHLENDORF HM, HOFFMAN DJ, SAIKI MK and ALDRICH TW (1986) Embryonic mortality and abnormalities of aquatic birds: Apparent impacts of selenium from irrigation drain-water. Sci. Tot. Environ. 52 49-63.

PHILLIPS DJH (1977) The use of biological indicator organisms to monitor trace metal pollution in marine and estuarine environments - A review. Environ. Pollut. 13 281-317.

REID M and HACKER CS (1982) Spatial and temporal variation in $\mathrm{Pb}$ and $\mathrm{Cd}$ in the Laughing Gull, Larus atricilla. Mar. Pollut. Bull. 13 387-389.

SADIQ M, ALAM I., EL-MUBAREK A. and AL-MOHDHAR HM (1989) Preliminary evaluation of metal pollution from wear of auto tires. Bull. Environ. Contam. Toxicol. 42 743-748.

SCHEUHAMMER AM (1987) The chronic toxicity of aluminium, Cd, mercury and $\mathrm{Pb}$ in birds: A review. Environ. Pollut. 46 263-295.

SCHOONBEE HJ and VAN DER MERWE CG (1989) Investigations into the effects of sewage, industrial and gold mine effluents on the water quality and faunal conditions of a stream in the Transvaal, 
South Africa. In: Luria M, Steinberger Y and Spanier E (eds.) Environmental Quality and Ecosystem Stability Vol. IV-A, Environmental Quality, Jerusalem, Israel. 401-418.

SCHUURMAN JFM (1932) A seasonal study of the microflora and microfauna of the Florida Lake, Johannesburg. Trans. Roy. Soc. S. Afr. 20 33-38.

STANDARD METHODS (1989) Standard Methods for the Examination of Water and Wastewater (17th edn.), American Public Health Association (APHA), Washington.

STEENKAMP VE (1992) The Bioaccumulation of Selected Heavy Metals in the Crab Potamonautes warreni from Industrial and Mine Polluted Freshwater Ecosystems. Unpublished M.Sc. Thesis, Rand Afrikaans Univ., Johannesburg. $166 \mathrm{pp}$.

STEENKAMP VE, DU PREEZ HH, SCHOONBEE HJ, WIID AJB and BESTER MM (1993) Bioaccumulation of iron in the freshwater crab (Potamonautes warreni) from three industrial, mine and sewage polluted freshwater ecosystems in the Transvaal. Water SA 19 281-290.

STENSTRÖM T and VAHTER M (1974) $\mathrm{Cd}$ and $\mathrm{Pb}$ in Swedish commercial fertilizers. Ambio 3 91-92.

TAYLOR PB (1997) Red-knobbed Coot Fulica cristata. In: Harrison JA, Allen DG, Underhill LG, Herremans M, Tree AJ, Parker V and Brown CJ (eds.) The Atlas of Southern African Birds, Volume 1. BirdLife SA, Johannesburg. 342-343.

TAYLOR PB, NAVARRO RA, WREN-SARGENT M, HARRISON JA and KIESWETTER SL (1999) Total CWAC Report: Coordinated Waterbird Counts in South Africa, 1992-1997. Avian Demography Unit, Univ. of Cape Town, Cape Town. 251 pp.

THE ROODEPOORT MAIL (1898) Florida and Maraisburg News: The New Township. The Roodepoort Mail 26-01-1898.

UNDERHILL LG, TREE AJ, OSCHADLEUS HD and PARKERV (1999) Review of Ring Recoveries of Waterbirds in Southern Africa. Avian Demography Unit, Univ. of Cape Town, Cape Town. 119 pp.

VAN EEDEN PH (1990) Die Voorkoms en Akkumulering van Geselekteerde Swaarmetale in die Rioolbesoedelde, Organiesverrykte Elsburgspruit-Natalspruit Vlei-Ekosisteem. Unpublished M.Sc. Thesis, Rand Afrikaans Univ., Johannesburg. 397 pp.

VAN EEDEN PH (1994) Bio-accumulation of Selected Metals in the Organs and Tissues of the Red-knobbed Coot, Fulica cristata, Reed Cormorant, Phalacrocorax africanus and Sacred Ibis, Threskiornis aethiopicus, in Mine and Industrial Polluted Freshwater Ecosystems. Unpublished Ph.D. Thesis, Rand Afrikaans Univ., Johannesburg, $165 \mathrm{pp}$.

VAN EEDEN PH (2003) Seasonal change in metal concentrations in selected tissues of the Red-knobbed Coot, Fulica cristata, from a metal-polluted wetland. Water SA 29 91-99.
VAN EEDEN PH and SCHOONBEE HJ (1991) Bio-accumulation of heavy metals by the freshwater crab Potamonautes warreni from a polluted wetland. S. Afr. J. Wildl. Res. 21 103-108.

VAN EEDEN PH and SCHOONBEE HJ (1992) Concentrations of heavy metals in organs and tissues of the Red-knobbed Coot. Ostrich 63 165-171.

VAN EEDEN PH and SCHOONBEE HJ (1993) Metal concentrations in sediments and some organisms from a polluted wetland. S. Afr. J. Wildl. Res. 23 12-16.

VAN EEDEN PH and SCHOONBEE HJ (1996) Metal concentrations in liver, kidney, bone and blood of three species of birds from a metal-polluted wetland. Water SA 22 351-358.

VARIAN (1989) Flame Atomic Absorption Spectrometry - Analytical Methods. Varian Techtron Pty Limited, Mulgrave, Victoria, Australia.

VENTER AJA (1991) 'n Ekologiese Ondersoek van die Florida Meer, Roodepoort, met Verwysing na die Biologiese Beheer van Probleemplante deur Gebruik te mak van die Sjinese Graskarp Ctenopharyngodon idella. Unpublished M.Sc. Thesis, Rand Afrikaans Univ., Johannesburg. 197 pp.

VENTER AJA and SCHOONBEE HJ (1991) The use of triploid grass carp, Ctenopharyngodon idella (Val.), in the control of submerged aquatic weeds in the Florida Lake, Roodepoort, Transvaal. Water SA 17 321-326

VERMAAK JF (1972) 'n Ekologiese Studie van Germistonmeer met Spesiale Verwysing na Besoedelingstoestande en die Effek Daarvan op Akwatiese Makro-Invertebraatfauna. Unpublished M.Sc. Thesis, Rand Afrikaans Univ., Johannesburg.

VILJOEN FC (1974) Die Rol van Versteuring deur Minerale en Organiese Stowwe op Faunistiese Toestande van Riviere in die Witwatersrandse Gebied van die Vaalriviersisteem. Unpublished Ph.D. Thesis, Rand Afrikaans Univ., Johannesburg.

VILJOEN FC, PHILLIPS AL, CHRISTODOULOU LS and HAYNES RE (1985) An Input Output Study on Various Constituents in the Water after Passage Through a Section of the Natalspruit Wetland. Rand Water Board Laboratory Report No. 85/1, Johannesburg. 98 $\mathrm{pp}$

WHITE DH and KAISER TE (1976) Residues of organo-chlorines and heavy metals in Ruddy Ducks from the Delaware River, 1973. Pest. Monit. J. 9 155-156.

WHITE DH, KING KA, MITCHELL CA and MULHERN BM (1986) Trace elements in sediments, water and American Coots (Fulica americana) at a coal-fired power plant in Texas, 1979-1982. Bull. Environ. Contam. Toxicol. 36 376-383.

WILLIAMS CH and DAVID DJ (1973) The effect of super-phosphate on the Cd content of soils and plants. Aust. J. Soil Res. 11 43-56.

ZAR JH (1974) Biostatistical Analysis. Prentice-Hall, Inc., London. 620 pp. 